
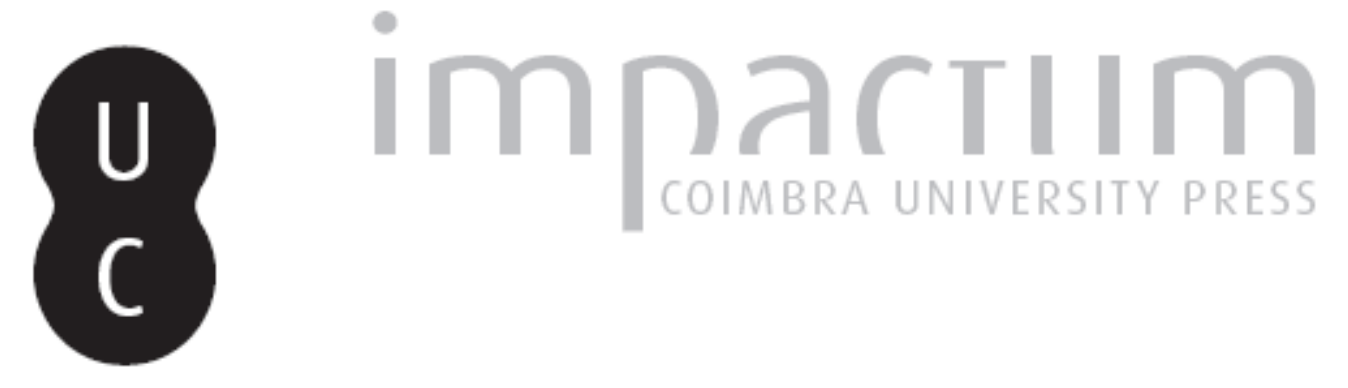

\title{
Lucian's satire or Philosophy on sale
}

\author{
Autor(es): $\quad$ Pinheiro, Marília P. Futre
}

Publicado por: Annablume Clássica; Imprensa da Universidade de Coimbra

URL persistente:

URI:http://hdl.handle.net/10316.2/37007

DOI:

DOI:http://dx.doi.org/10.14195/1984-249X_15_7

Accessed : $\quad$ 26-Apr-2023 13:10:29

A navegação consulta e descarregamento dos títulos inseridos nas Bibliotecas Digitais UC Digitalis, UC Pombalina e UC Impactum, pressupõem a aceitação plena e sem reservas dos Termos e Condições de Uso destas Bibliotecas Digitais, disponíveis em https://digitalis.uc.pt/pt-pt/termos.

Conforme exposto nos referidos Termos e Condições de Uso, o descarregamento de títulos de acesso restrito requer uma licença válida de autorização devendo o utilizador aceder ao(s) documento(s) a partir de um endereço de IP da instituição detentora da supramencionada licença.

Ao utilizador é apenas permitido o descarregamento para uso pessoal, pelo que o emprego do(s) título(s) descarregado(s) para outro fim, designadamente comercial, carece de autorização do respetivo autor ou editor da obra.

Na medida em que todas as obras da UC Digitalis se encontram protegidas pelo Código do Direito de Autor e Direitos Conexos e demais legislação aplicável, toda a cópia, parcial ou total, deste documento, nos casos em que é legalmente admitida, deverá conter ou fazer-se acompanhar por este aviso.

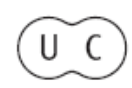




\section{5}

jul/dez

2015

issn 2179-4960

e-issn 1984-249-X
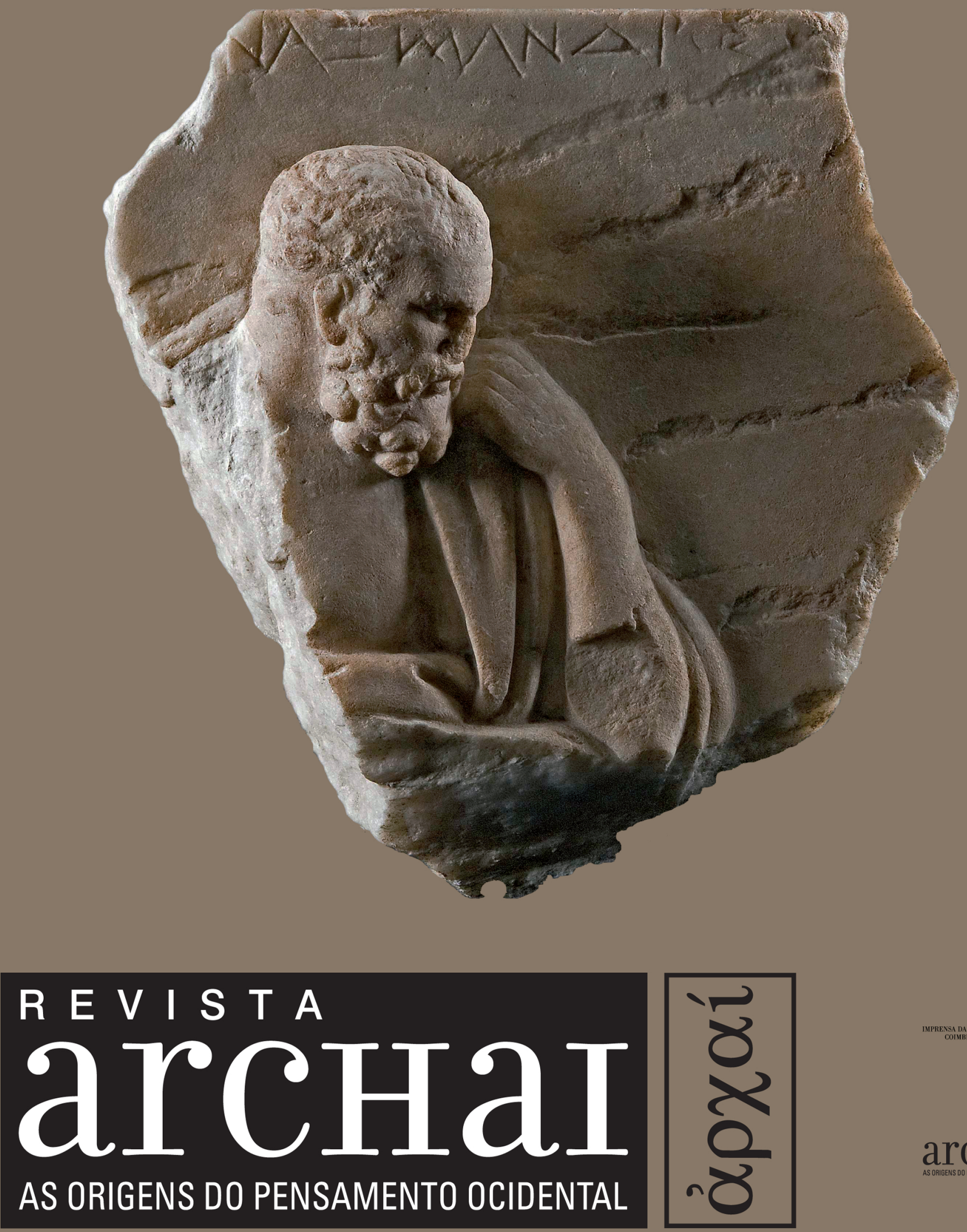

ARCHAI JOURNAL: ON THE ORIGINS OF WESTERN THOUGHT

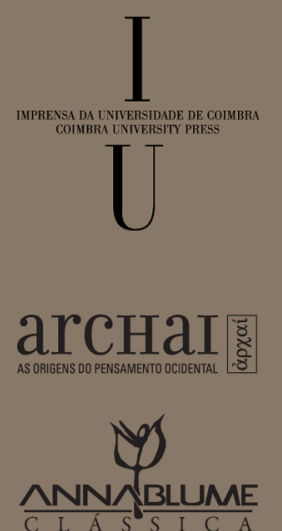




\section{LUCIAN'S SATIRE OR PHILOSOPHY ON SALE}

PINHEIRO, M. P. F. (2015). Lucian's Satire or Philosophy on Sale. Archai, n. 15, jul. - dez., p. 71-79

DOI: http://dx.doi.org/10.14195/1984-249X_15_7

ABSTRACT: Famous philosophers and their conceits became the target of Lucian's satirical verve in many of his works. However, in Philosophies for Sale (Auctio Vitarum), Lucian offers an original view of philosophy. Just like a marketing expert would, Lucian treats philosophy as a product that is designed to satisfy the customers' needs, and whose nature is decisively influenced by consumer forces. My discussion is inspired by the main analytic tools and the basic core concepts of marketing. I argue that, in Philosophies for Sale, Lucian revolutionized the established concept that philosophy as well as human sciences in general are not governed by market rules. On the contrary, he has shown that philosophy, just like any other activity involving a trade of values between two parties, can be assessed from an economic perspective and that, consequently, must be viewed as customer-creating value satisfactions, being subject to the law of supply and demand.

KEYWORDS: Lucian, Philosophies for Sale, marketing, philosophy.
* Universidade de Lisboa Portugal-mfutrepinheiro@ gmail.com

\section{Marília P. Futre Pinheiro}

Lucian was a singular and emblematic author of the $2^{\text {nd }}$ century A.D. Despite being born in Syria, at the edge of the Hellenic world, he managed to become part of it due to his persevering efforts. Thanks to his wanderings, his everlasting curiosity, and his open mind, he passionately and enthusiastically got involved in every single "novelty" of his epoch. After having pursued an oratorical career both as a forensic speaker and a sophist in Asia Minor, Greece, Italy, Gaul and Egypt, he decided to pursue a new interest and devoted himself to the philosophical dialogue, a literary "genre" deeply rooted in tradition. The satirical and dramatic works Lucian produced in this sphere earned him widespread and lasting fame. He brilliantly expressed his sarcastic and corrosive vein and irreverently displayed his sophistic culture when criticizing society at large: gods, heroes, legendary characters or real men, and their vanity, vices, hypocrisy and irrational superstitions, religion and religions, philosophy and its various sects, and conventional morality. All this comes to life thanks to his imagination. In his work even abstract ideas are represented by real characters that, because of it, become all the more picturesque.

Famous philosophers and their doctrines became the target of Lucian's satirical verve in many of his works. However, as George Bragues notes, 
It would certainly shock many of Lucian's commentators and readers that his works can be plumbed for philosophic purposes, much less economic insight. After all, Lucian is typically classified as a satirist who specialized in the comedic-dialogue form to deride the foibles and pretensions of the leading figures and symbols of Greek-Roman civilization. In this view, philosophy features in Lucian's work only as one of the chief targets of his satire, and economics and philosophy combine with the auction in The Sale of Philosophers only as a satirical device to deflate the leading schools of thought. ${ }^{1}$

In his original study, Bragues interprets the model of the philosophical market culled from Lucian in Hermotimus (153-65?) and in Philosophies for Sale (160-70?) as offering a compelling if somewhat inadequately developed economic theory of

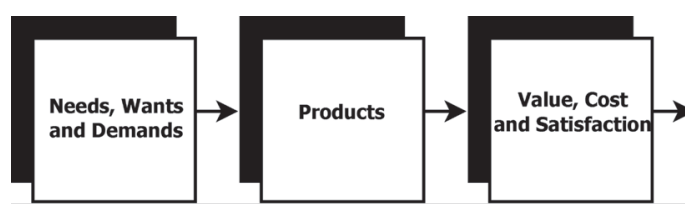

philosophy. Hermotimus, a masterpiece of ancient skepticism, with disturbing nihilistic undertones, criticizes all metaphysical and philosophical dogmatism in general, and the second depicts a fictional auction of the major philosophical schools of the Greek philosophical tradition. My discussion will be focused on the second of those dialogues (Vitarum Auctio), and will be inspired by the main analytic tools now available to marketing experts. Marketing may be defined as

the management process responsible for identifying, planning and executing activities according to the aims of an organization as well as for anticipating customer requirements to create exchanges that satisfy individual and organizational objectives.

Any structural change taking place at an economic, social or political level presupposes ability to act, knowledge and skills, that is, it requires a particular strategy. And for any strategy to be successful, it is necessary to make adequate use of the means available to us so as to be able to obtain maximum return. The very first and ultimate aim of a strategy is to obtain tactical results which are assessed in terms of efficacy.
Marketing strategy is customer- oriented, rather than product-oriented. For the marketing strategists,

The difference between marketing and selling is more than semantic. Selling focuses on the needs of the seller, marketing on the needs of the buyer. Selling is preoccupied with the seller's need to convert his product into cash; marketing with the idea of satisfying the needs of the customer by means of the product and the whole cluster of things associated with creating, delivering, and finally consuming it. Most important, what it offers for sale is determined not by the seller but by the buyer. The seller takes his cues from the buyer in such a way that the product becomes a consequence of the marketing effort, not vice versa." ${ }^{2}$

Marketing core concepts may be summarized as follows (Figure 1$)^{3}$ :

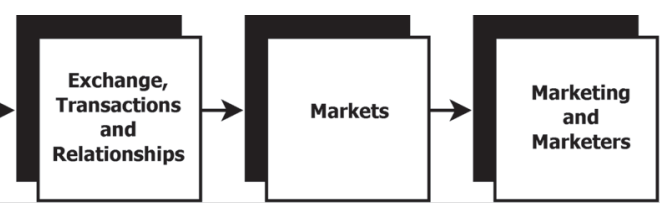

Fig.1 - The core concepts of Marketing

1. Needs, Wants, Demands

2. Products

3. Value, Cost and Satisfaction

4. Exchange, Transactions, and Relationships

\section{Markets}

The fact that all human beings have needs and wants lies at the core of the marketing discipline. "A human need is a state of felt deprivation of some basic satisfaction. ${ }^{4}$

These needs are not created by their society or by marketers, they exist in the very texture of human biology and the human condition. ${ }^{5}$

Marketers do not create needs, they influence wants. Wants are desires for specific satisfiers of these deeper needs, and are dependent on social and technological factors. As Kotler notes,

An American needs food and wants an hamburger, needs clothing and wants a Pierre Cardin suit, needs
1 Bragues (2004, p. 227).

2 Levitt (1994, p. 9-10).

3 The figures are taken from Kotler (1991).

4 Definitions in italics are taken from Kotler (1991).

5 Kotler (1991, p. 5). 
esteem and buys a Cadillac. In another society, these

6 Id., ibid.

7 Id., ibid.

8 The definitions of "search goods", "experience goods", and "credence goods" are taken from Bragues 2004, p. 230 and 232

9 Kotler 1991, 7

10 See Bagozzi 1994, 71

11 Kotler 1991, 9

12 Id. ib. 10

13 Id. ib.11.

needs are satisfied differently: the Balinese satisfy

their hunger with mangoes, their clothing needs with

a loincloth, their esteem with a shell necklace. While people's needs are few, their wants are many ${ }^{6}$.

"Demands are wants for specific products that are backed up by an ability and willingness to buy them." "Wants become demands when backed up by purchasing power. Many people want a Cadillac; only a few are able and willing to buy one" ${ }^{7}$.

The products are the motive for the transaction. Kotler defines products broadly to cover "anything that can be offered to someone to satisfy a need or want. " There are physical products (e.g. an automobile, a television set) and intangible, abstract ones (places, activities, ideas). Separately or all together, they are designed to satisfy the customers' needs. The so-called "marketing myopia" consists in giving preference to the product itself over the services it provides to the consumer. There are obviously some products that offer at the outset more guarantees than others and that provide consumers with immediate satisfaction. Economists distinguish between "search goods", "experience goods", and "credence goods". A search good is "anything whose characteristics and quality can be examined at the point of purchase" as nails and two-by-fours; an experience good is anything "whose true nature can be discovered only after purchase". Examples of experience goods include food and used cars. Contrarily, the quality or the truth value of a credence good "cannot be readily settled either before or after someone invests in it" ${ }^{8}$. Philosophy belongs to this last category, because the customers can never really tell whether they had the return of their investment, that is to say, whether they received the product they bargained for.

The consumers have at their disposal a number of products that might satisfy a given need. These alternatives constitute their product choice set. However, each product has a different capacity to satisfy different needs. These are called their need set. On the other hand, the product choice is oriented by the concepts of value, cost and satisfaction. "Value is the consumer's estimate of the product's overall capacity to satisfy, his or her needs". However, this variable is closely con- nected to other variables, such as cost. Therefore, the consumer will consider the product's value and price before making a choice. He will choose the product that presents a more favorable ratio between cost/quality.

"Exchange is the act of obtaining a desired product from someone by offering something in return". A transaction consists of a trade of values between two parties. In order that a transaction takes place, an agreement must have been reached. Consequently, transaction also presupposes the process of trying to arrive at mutually agreeable terms, that is to say, to a negotiation. This means that, in the most generic sense, the marketer is seeking "to elicit desired responses to some object from a target audience" network of behavioral relationships with the other part. This is called social marketing. Social marketing attempts to determine the dynamics and nature of the exchange behavior in social relationships ${ }^{10}$.

A market consists of all the potentials customers sharing a particular need or want who might be willing and able to engage in exchange to satisfy that need or want. "Economists use the term market to refer to a collection of buyers and sellers who transact over a particular product or product class" ${ }^{11}$.

A marketer is someone seeking a resource from someone else and willing to offer something of value in exchange. "The marketer is seeking a response from the other party, either to sell something or to buy something. The marketer, in other words, can be a seller or a buyer" ${ }^{12}$. Selling benefits is one of the main tasks of marketers, whose function is not that of creating needs but rather of emphasizing that certain products might satisfy buyers' needs or (material and spiritual) wants. The consumers' satisfaction is the ultimate goal of the marketer.

Marketing management is, thus, the process which focuses on working with markets (through planning, promotion and distribution of ideas, goods and services), in order to create exchanges that fulfill both individual and organizational goals and needs. Marketing management is essentially demand management ${ }^{13}$.

The goals//aims of marketing are:

1. to persuade the customer that the brand being sold is the best. 
2. to persuade the customer that the present product on sale is the best.

3. to persuade the buyer that our product is the one that best satisfies his/her needs.

4. to persuade the customer that the need satisfied by our product is the most important one. In short, it can be said that marketing does not create needs, it sells benefits.

Modern theories of consumer-choice behavior indicate that a buyer's purchase decisions are highly influenced by the buyer's cultural, social, personal, and psychological factors. As Kottler notes, "Cultural factors exert the broadest and deepest influence on consumer behavior." ${ }^{14}$ (Figures 2 and 3).

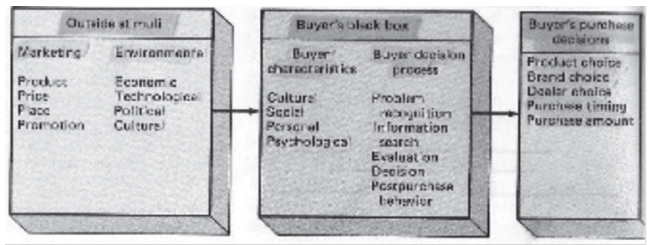

Fig. 2 - Buyer behavior

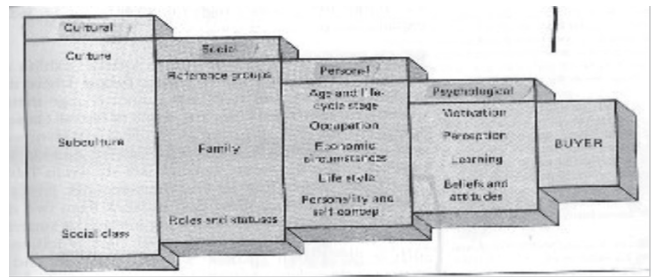

Fig. 3 - Factors influencing behavior

A person's buying choices are influenced by four major psychological factors: motivation, perception, learning, beliefs and attitudes. Figure 4 illustrates Maslow's Theory of Motivation.

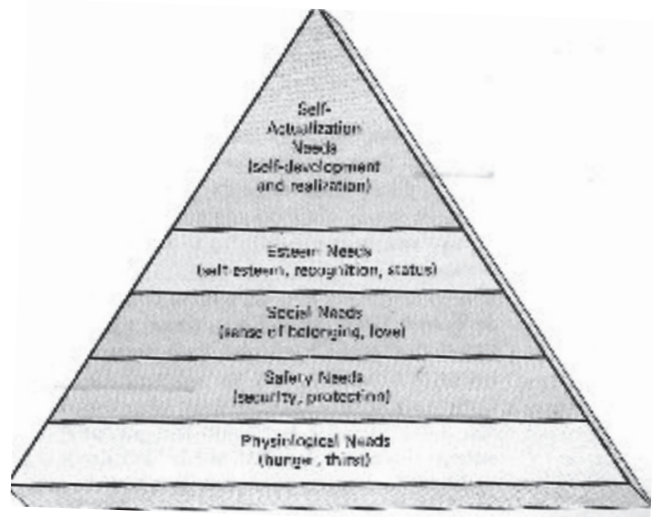

Fig. 4 - Maslov's hierarchy of needs
According to Maslow, human needs are arranged in a hierarchy, from the most pressing to the least pressing. In their order of importance, they are physiological needs, safety needs, social needs, esteem needs, and self-actualization needs.

Lucian's economic insight reveals a keen understanding that the philosophy industry is a customer-satisfying process, and that to produce eager followers/customers in vast numbers, the entire corporation must be viewed as customer-creating value satisfactions. As a marketer theorist would do, Lucian treats philosophy as a product that is capable of delivering satisfaction of a want or need. But, in general terms, which needs are satisfied by this product? The answer to this question may be found in Hermotimus, the other dialogue that complements Lucian's economic perspective of philosophy. The study of philosophy aims at reaching the truth and, ultimately, obtaining true happiness. However,

Part of what makes individuals overpay for the truth claims of elaborate philosophies is that they are not simply concerned about reaching the truth. They pay more in the hope of obtaining additional goods not necessarily consistent with the truth. Among these goods is firm conviction in a set of opinions that absolutely withstand future contingencies. Another is the gratification of pride, manifest in the longing to distinguish oneself from the common run of humanity. ${ }^{15}$

On the other hand, the study of philosophy is a risky asset, once it "constitutes an investment in human capital in which the costs are immediate and certain, whereas the benefits are delayed and uncertain. ${ }^{16}$ So, philosophical allegiances are costly to reverse. As we said before, philosophy's risk is accentuated by its being a credence good.

Philosophy belongs to this category because the different teachings typically advanced make claims about matters such as God, being, truth, the human soul, the good life, morality, beauty, and the best political order - that can never be verified. ${ }^{17}$

Under these circumstances, potential philosophers and all those who would like to associ-
14 Id. ib.165.

15 Bragues 2004, 236

16 Id., ib. 232.

17 Id., ib. 233. 
ate themselves with a brand name, that is, with a long-standing school or philosophical model deeply rooted in tradition can choose from a wide range of products (product choice set) and select the one that best suits their preferences and intellectual taste (need set). Another type of needs may be taken into account when making a choice - such is the case with the social advantages of belonging to a community that shares common needs and aspirations. Hence, the market tends to be stable, both in terms of supply and demand. It is obvious that the specific nature of the product and the high-standard prerequisites substantially limit and condition the universe of both suppliers and potential philosophers. The investment return, which is only obtained in the long term (if obtained at all, as there are no certainties) and the high costs limit and condition demand. Nevertheless, this universe is wide enough to hold competition amongst sellers and the struggle for market share. Another restriction sellers and customers are faced with is what is currently called job availability or "labor market" which is obviously limited when it comes to this restricted number of highly educated professionals with highly refined theoretical talents. In spite of this, there is strong competition amongst highly qualified competitors.

The Sale of Philosophers begins with the preparation of the auction of the major philosophical schools in the ancient Greek-Roman world. Zeus oversees the "business" and Hermes is both the auctioneer and the seller. Hermes starts by announcing the goods to be auctioned: "philosophies of every

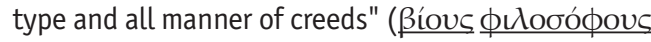

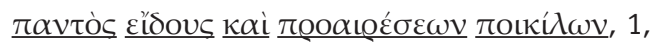
$7-8)^{18}$. The supply is highly diversified as there are theories that cater to virtually everybody's taste: some theories advocate the harmony of the cosmos while others sustain that the physical world is the result of the random and mechanical movement of the atoms; some defend the existence of a divine being whereas others openly admit to their atheism; some uphold the existence of the soul while others claim that human nature is nothing but matter; some are more theoretical as opposed to others with more practical aims; some are grounded on moral values whereas others favor a society with loose customs; some aspire to the attainment of absolute truth while others are content to go no further than analyzing superficial pettiness. Just before the auction begins, Hermes announces that "if anyone is unable to pay cash, he is to name a surety and pay next year"

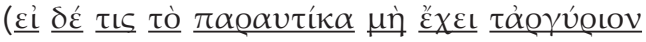
$\underline{\kappa \alpha \tau \alpha \beta \alpha \lambda \dot{\varepsilon} \sigma \theta \alpha \mathrm{L}}, \underline{\varepsilon \dot{\iota}} \underline{v \varepsilon \dot{\varepsilon} \omega \tau \alpha} \underline{\varepsilon \dot{\kappa} \kappa \dot{\sigma} \sigma \varepsilon \mathrm{L}} \underline{\kappa \alpha \tau \alpha \sigma \tau \eta \dot{\sigma} \sigma \alpha \varsigma}$

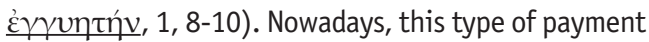
is commonly referred to as "credit sale", a system with an underlying pricing policy, which is a current marketing strategy aimed at enticing consumers and convincing them to buy a product. Then, the various models/schools of philosophy are put on sale one after the other: the Pythagoreans, the Cynics, the Cyrenaic, Democritus and Heraclitus (in the same package deal!), the Stoics, the Academic/ Socratic, the Epicureans, the Peripatetic, and finally the Skeptics. As Hermes announces the different models/ schools of philosophy, he briefly characterizes each one, highlighting its most "sellable" features, in other words, what is more attractive to the consumer. "Products" are thus differentiated by their most outstanding attributes, that is, the so-called "product distinctive factors". "In such a market, demand will be directly related to perceived quality - which is to say, the degree to which the attributes of a given teaching are consistent with philosophy consumers' preferences." ${ }^{19}$ The price offered for the product results from the combination of this assessment of costs, risk evaluation and expected return. The most successful products are the ones that offer the best price/quality ratio. There are still other factors that can influence one's choice and therefore condition the sale, such as, the teacher's credibility, his character, the reputation of the various schools, the philosophers' physical appearance or popularity that is determined by the number of followers they have who, after all, provide the market share.

The Pythagorean model ("the fellow with the long hair", 2, 2-3) is the first one to be put up for sale. Hermes describes it as "a first-class soothsayer, an expert in arithmetic, astronomy, charlatanry, geometry, music and quackery" (2, 12-13), also emphasizing the brand name of Pythagoras' philosophical system, the "noblest of philosophies for sale": the notion of an ordered and harmonious 
universe and the doctrine of metempsychosis. The school also insists on the notion of deity as number, mind and harmony, and on the idea that numbers played a primordial role in Nature. When the buyer asks about Pythagoras' lifestyle, he is visibly wellimpressed when he hears that Pythagoras had been educated in Egypt. This information functions as an indirect indicator of quality, demonstrating the unequivocal relationship between cost/quality. Not even the claims of vegetarianism and of a cathartic and aesthetic way of living seem to discourage the buyer (or better, buyers) who treasures knowledge and wisdom, thus meeting the demands of high intellectual and spiritual standards. The reincarnation doctrine, the belief in cosmic harmony as well as in a transcendent order secure ethical and moral standards which, in addition, are important in terms of an individual's social recognition.

The Pythagorean model/Pythagoras is finally sold for ten minas, honorably ranking fourth among the ten auctioned models.

The second model to be put up for sale, the Cynic one ("the dirty one from the Black Sea, with the valet slung about him, and the sleeveless shirt", 7,1-4), will clearly fetch a much lower price. The Cynic's ideal proclaimed the return to Nature and simplicity, and encouraged individuals to forego worldly goods and give up the most basic comforts of civilized life. This ideal could be attained through intensive training of the mind (askesis), making the body inure to pain. The status of citizen of the world (cosmopolites) that Diogenes, the main theorizer of the Cynic school, claimed for himself, also presupposed being free from all social constraints and having unlimited freedom of expression (parrhesia). However, and despite the fact that, in the buyer's eyes, some of these principles may be an asset to the Cynic's approach as, for instance, the philosophical ideal of membership in a global community, the physical appearance of the model is so repulsive that the buyer is immediately put off:

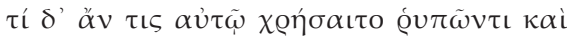

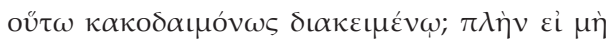

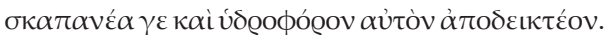
$(7,13-16)$
What use could a man make of him, filthy as he is, and in such a wretched condition? However, he might be made a shoveller or a drawer of water.

Moreover, the transgression of basic social norms and the utter lack of shame (anaideia) turn off the potential customer who considers that model to be "abominable and inhuman".

$\hat{\alpha} \delta \dot{\varepsilon} \mu \alpha \dot{\alpha} \lambda \iota \sigma \tau \alpha \delta \varepsilon \tilde{\imath} \pi \varrho o \sigma \varepsilon \tilde{\imath} v \alpha \mathrm{L}, \tau \alpha \tilde{v} \tau \alpha \dot{~} \dot{\varepsilon} \sigma \tau \iota \nu$

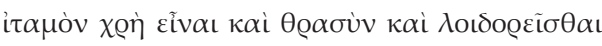

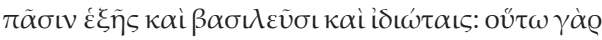

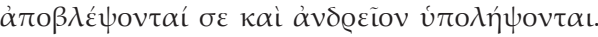

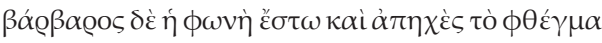

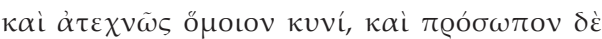

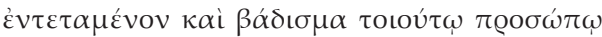

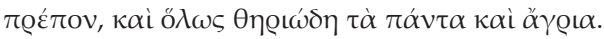

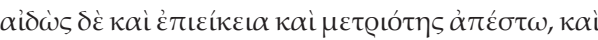

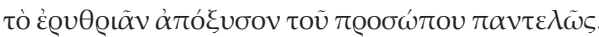

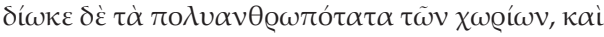

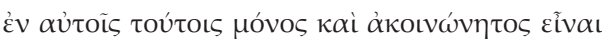

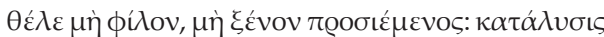

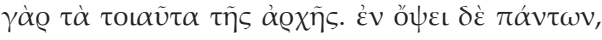

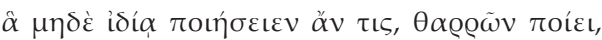

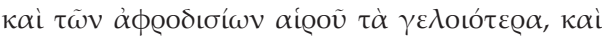

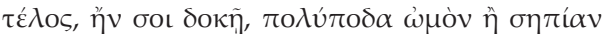

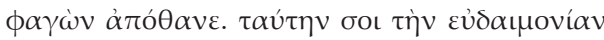
$\pi \varrho 0 \xi \varepsilon v o \tilde{u} \mu \varepsilon v .(10,2-19)$

The traits that you should possess in particular are these: you should be impudent and bold, and should abuse all and each, both kings and commoners, for thus they will admire you and think you manly. Let your language be barbarous, your voice discordant and just like the barking of a dog: let your expression be set, and your gait consistent with your expression. In a word, let everything about you be bestial and savage. Put off modesty, decency and moderation, and wipe away blushies from your face completely. Frequent the most crowded place, and in those very places, desire to be solitairy and uncommunicative, greeting nor friend nor stranger; for to do so is abdication of the empire. Do boldly in full view of all what another would not do in secret; choose the most ridiculous aways of satisfying your lust; and at the last, if you like, eat a raw devilfish or squid, and die. That is the bliss we vouchsafe you. 
Yet, and once he "might do at a pinch for a boatman or a gardener", the customer makes a very low and humiliating bid: only two obols, or onethree-hundredths of a mina. Such a low price is an indicator of low quality and definitively makes the Cynic model attractive only to the lowest and least educated social classes. Hermes is also relieved: "we shall be glad to get rid of him because he is annoying and loud-mouthed and insults and abuses everybody without exception."

The three next philosophical models, i.e. the Cyrenaic, the Democritean and the Heraclitean, are left unsold. The first of these, introduced to us "in the purple cloak, with the wreath on his head" (12,1-2), considered the pursuit of pleasure as the ultimate aim of life, being therefore announced by Hermes as "high-priced wares, wanting a rich buyer." Yet, the pursuit of pleasure is not the buyer's main goal as he hopes the product to prove useful in a different way. The logic of pleasure, and its self-indulgence principle, goes against established morality. This is why he is suspicious of a model that provides him with merely pleasure and lust as an investment return $^{20}$, and concludes that maybe someone else, but not him, might be taken in by this hedonist, wild and lawless lifestyle.

The other two, promoted as a package deal, are announced as being "the one from Abdera who laughs" $(13,2)$ (i.e. Democritus of Abdera, the propounder of the atomic theory, which claims that the physical world is made up of an infinite number of atoms that move randomly through the void) and "the one from Ephesus who cries" $(13,3)$ (i.e. Heraclitus of Ephesus) who holds that fire is the first principle, and that everything continually changes. So, as Democritus claims, the world appears to be a combination of opposing forces, the so-called "harmony of opposite tensions".

Despite being announced by Hermes as "the two best philosophies.., the two that are sagest of all" $(13,5-6)$, the despise the former shows for human beings that he considers laughable, being nothing more than atoms, and the latter's pessimistic worldview, particularly when predicting great conflagrations and the collapse of the universe ${ }^{21}$, combined with his enigmatic discourse, offer little consolation to mankind. No wonder, then, that the buyer believes that nobody in his right sense will buy any of those theories.

Socrates, who is also the spokesman of the Platonic philosophy, is the figure behind the model that comes next. This model is pictured as "a righteous and intelligent philosophy, the height of sanctity" (15, 3-4), an obvious allusion to the philosopher's integrity and character - Socrates declined the chance to escape Athens given to him by his disciple Criton in order to keep true to the moral law that had always guided him. Coming from the founder of ethics, this unity of thought and action undoubtedly enhances credibility and vouches for the high quality and value of Socrates' teachings, attracting a large group of supporters and followers.

Also relevant is the erotic component of the Socratic/Platonic philosophical system, especially Socrates' confessed pederastic inclinations. However, as it is mentioned, this inclination should be seen from a broader perspective of the quest for truth where the erotic activity is purely spiritual, being based more on love and attraction for the soul than for the body. This puts the prospective buyer's mind at rest as his son belongs to that large demographic group of philosophy's consumers mainly made up of young men who aim to acquire lasting knowledge through the philosophers' teachings. There is a great chance to obtain return for that investment in education given the fact that the potential philosophers are young adults. This fact not only justifies that investment but it also ensures that human capital will become profitable.

Two of the most remarkable/best-known features of the Socratic/Platonic philosophy are also mentioned: the ideal state described in Plato's Republic and the theory of ideas, both of which are perceptible only to an elite that aims at human excellence and at acquiring notoriety and fame, that is, to philosophers and politicians.

The Academic/Socratic model has got all it takes to achieve marketing success and, indeed, it does so: Dion of Syracuse, Plato's disciple and friend, pays two talents for this model, which amounts to 120 minas, the highest price of the auction. Lucian seems to be saying that politicians are the social class from where most of the potential customers come, because 
as they want to be able to support and justify their action on a theoretical level, they wield the greatest potential purchasing power in the philosophy market. In turn, "philosophers would be tempted to supply political counsel, given the opportunity to gain access to government resources, to enhance the credibility of their theories, and to acquire fame." ${ }^{22}$.

Next, the Epicurean moderate version of hedonism, "agreeable and fond of good eating" $(19,8)$, fetched two minas, a price 60 times lower than that of the Academic model.

The men who frequent the public square are waiting for the Stoic model in great numbers, which, at the outset, seems to suggest that this is a high quality "product" as it is of interest to a segment of the population mainly made up of statesmen, lawyers, and men of affairs. What, then, sets this philosophical model apart from all the others to have the support of so many fans? The most plausible answer to this question is that what is on sale is precisely "virtue itself, the most perfect of philosophical lives" $(20,5)$.

Stoicism enjoyed great fame in the Antiquity because of its austerity and irreproachable morality. The Stoics believe true morality is based on knowledge. Wise men lead a life guided by Reason and God, or by Nature, and are free from passions and indifferent to physical and material goods, as members of a grandiose universal order. However, and even though the Stoic model uses a very technical and rather esoteric vocabulary, inaccessible to outsiders, wisdom attained through effort and hard work as well as the practical results of its implementation in daily life (i.e. the acquisition of wealth, health, and the like) ${ }^{23}$, make it a very popular model appealing to a large crowd of people. But this is surely not the only reason that renders Stoicism a high-priced doctrine which obtains the third-highest price (twelve mina) at the philosophy market. What then makes such a personal and monetary investment so appealing? And why does it give so much satisfaction? And, which needs does it satisfy? A plausible answer is that, besides providing practical knowledge, the emphasis on logical and rhetorical procedures enables the citizen to master the art of persuasion, a much needed weapon for the political combat fought in political councils and courts of law. Moreover, since the ultimate goal of Stoicism is "to reach the summit of virtue" $(23,6)$, Stoic philosophers appear as members of an elite, which somehow legitimates their political superiority over the lower classes. Lastly, as Bragues argues, "Stoicism offers a psychological defense against the special risks of being politically involved in an unstable environment. ${ }^{24}$ and helps to endure the "constant threat of ruin by the emperor's caprices, jealousy, suspicions, and stratagems." ${ }^{25}$.

The Peripatetic model is "the height of intelligence, the one who knows absolutely everything!" $(26,3-4)$. Peripatetics' knowledge of natural science $^{26}$, and the combination of the esoteric and the exoteric, that is, of the writings accessible only to a select few intellects and the ones meant for the popular consumption, are what make the consumer acknowledge the usefulness of their teachings. It is precisely this diversified supply that enables this model to obtain a considerable market share both among the intellectuals and the general public, which leads to risk reduction. This school of philosophy thus successfully manages to rank second in price at the auction (it fetches 20 minas).

The last philosophical model to be auctioned is the Skeptic one. The Skeptics deny the existence of truth because there is always a chance of an argument being countered by another equally strong argument. Therefore, they claim that judgment should generally be suspended, and that the upshot of their wisdom is ... ignorance. This school of philosophy enjoys low popularity amongst consumers as it negates human beings' innate tendency to believe in something. Skeptics are, therefore, doomed to stand alone and see their group of supporters drastically dwindle away. The low demand for skepticism reflects itself in the low price this model fetched at the auction (only one mina).

\section{Conclusion}

It can be said that Lucian revolutionized the established concept that philosophy as well as human sciences in general are not governed by the rules of the market and, as such, are not tradable goods. However, Lucian has shown that philosophy,
22 Bragues 2004,245.

3 Pعoì $\tau \dot{\alpha} \pi 0 \tilde{\omega} \tau \alpha \kappa \alpha \tau \dot{\alpha}$

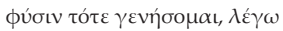

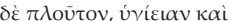

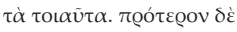

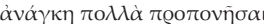
$\lambda \varepsilon \pi \tau о \gamma \varrho \alpha ́ \phi о เ \varsigma \beta เ \beta \lambda$ íoเ

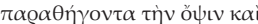

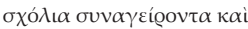

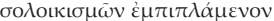

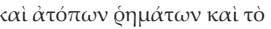

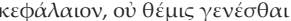

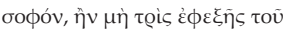

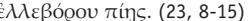
(I shall then devote myself to the chief natural goods, I mean wealth, health, and the light. But first I must go through many preparatoty toils, whetting my eyesight with closely-written books, collecting learned comments and stuffing myself with solecisms and uncouth words; and to cap all, a man may not become wise until he hás taken the hellebore treatment three times running.)

24 Bragues 2004, 247.

25 Id., ibid.

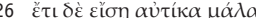

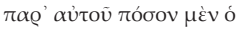

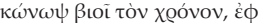

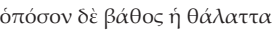

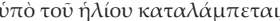

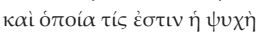
$\tau \tilde{\omega} \nu$ ò $\tau$ tóí $\omega v .(26,19-23)$ (Besides, he will tell you at once how long a gnat lives, how far down into the sea the sunlight reaches, and what the soul of an oyster is like.). 
ANDERSON, G. (1976). Studies in Lucian's Comic Fiction. Leiden, Brill.

(1982). Eros Sophistes: Ancient Novelists at Play.

values between two parties, can be assessed from

an economic perspective. Consequently, the sciences

of the mind as well as hard sciences can be subject

to the law of supply and demand. Just like in the

entrepreneurial world, there are several brand names

associated with the philosophy industry, and all of them sell benefits: Pythagoreanism sells Wisdom, the sublimation of the human condition and Hope of Resurrection; Cynicism puts on sale Truth, Equality and Freedom in all domains; the Cyrenaic offers Happiness, Pleasure and Luxury; Democritus' and Heraclitus' models sell respectively Derision and Pessimism; the Academic/Socratic model puts up for sale Rightness and Intelligence; Epicureanism offers Happiness and positive Pleasure; Virtue itself is Stoicism's most striking benefit, but Stoicism also sells Rhetorical Skills and Endurance; Intelligence and Knowledge are the trademarks of the Peripatetic model; and, finally, the Skeptic model offers ... Ignorance. As far as demand is concerned, it is significant that consumers opt for philosophical trends that cater to a wider range of human needs (intellectual, spiritual, moral and practical) than for theories that narrow down their logical and scientific spectrum. Moreover, human beings have the atavistic need to firmly believe in doctrines that help them endure daily hardship and attain the promised happiness, in life or in the afterlife. Men are consumers of philosophy nowadays and most certainly will continue to be so in the future, despite being aware they are investing in human capital that, as already noted, makes it more difficult to obtain short and even long-term return (at least, if that means attaining the truth). But, are philosophers convinced that there is no competitive substitute product for their major industry, the philosophy? The long-standing tradition of philosophy teaching and learning seems to confirm that philosophers are indeed convinced that there is no such substitute at all and, most likely, they are quite right.

\section{Bibliography}

ALLINSON, F. G. (1963). Lucian Satirist and Artist. New York, Cooper Square Publishers.

Chico: Scholars Press.

BAGOZZI, R. P. (1994). “Marketing As Exchange”, in: ENIS, B. M.; COX,K. K.; MOKWA, M. P. (eds.), Marketing Classics. A Selection of Influential Articles. New Jersey, Prentice Hall, p. 65-75.

BOMPAIRE, J. (1958). Lucien écrivain. Imitation et création. Paris, de Boccard.

BRAGUES, G. (2004). "The Market for Philosophers. An Interpretation of Lucian's Satire on Philosophy", The Independent Review, v. IX, n.2, p. 227-251.

BRANHAM, R. B. (1989). Unruly Eloquence: Lucian and the Comedy of Traditions. Cambridge, Mass, Harvard University Press.

HALL, J. A. (1981). Lucian's Satire. New York, Arno Press. JONES, C. P. (1986). Culture and Society in Lucian, Cambrige, Mass. - London, Harvard University Press.

KOTLER, Ph. (1991). Marketing Management. Analysis, Planning, Implementation and Control. New Jersey, Prentice-Hall, Inc.

LEVITT, T. (1994). "Marketing Myopia", in: ENIS, B. M.; COX,K. K.; MOKWA, M. P. (eds.), Marketing Classics. A Selection of Influential Articles. New Jersey, Prentice Hall, p. 3-19.

Submetido em Fevereiro de 2015 e aprovado em Março de 2015. 